
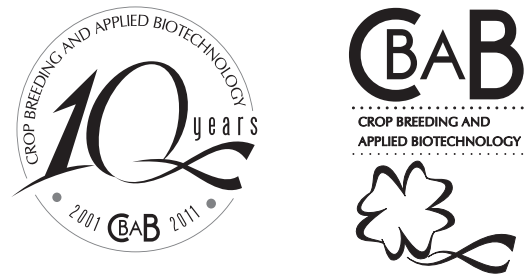

\title{
Prediction of genetic gains from selection in Arabica coffee progenies
}

Antonio Carlos Baião de Oliveira ${ }^{1,2 *}$, Antonio Alves Pereira ${ }^{2}$, Felipe Lopes da Silva ${ }^{2}$, Juliana Costa de Rezende ${ }^{3}$, César Elias Botelho $^{3}$ and Gladyston Rodrigues Carvalho ${ }^{3}$

Received 5 February 2010

Accepted 31 March 2010

\begin{abstract}
Gains from selection for yield were estimated in Arabica coffee progenies carrying rust-resistance genes. The experiment in augmented block design was installed in Três Pontas, state of Minas Gerais. Three blocks were established with six plants per plot, spaced $3.50 \times 0.90 \mathrm{~m}$, in 96 regular ( $F_{2}$ progenies) and two control treatments. The plant response to rust was evaluated on a grade scale in 2008. Yield (bags per hectare) was estimated in the growing seasons 2005 to 2008. Significant differences between treatments for yield were observed in all harvests, except 2005. The presence of genetic variability among progenies allowed significant gain from selection for yield. Under the experimental conditions of this study, selection for yield can be performed in the first high-yield year, without major losses compared to genetic gain from selection for yield when based on the mean of four harvests.
\end{abstract}

Key words: Coffea arabica; genetic improvement; bean yield; rust resistance; genetic progress.

\section{INTRODUCTION}

The cultivars available for cultivation of Arabica coffee are highly productive, but many have no genetic resistance to rust, the most deleterious disease (Carvalho et al. 2008b, Fazuoli et al. 2008). Coffee leaf rust, caused by Hemileia vastatrix Berk. et $\mathrm{Br}$, can cause yield losses between $2 \%$ and $50 \%$, depending on the planting system and year, plant age, crop management, and cultivar, among other factors (Zambolim et al. 2002). Cultivars with genetic resistance are however exempt from the use of pesticides, reducing production costs and risks of environmental contamination, whereas the yield potential is comparable to that of the best cultivars (Oliveira and Pereira 2008).
The source of resistance of most rust-resistant cultivars available is a germplasm designated Timor Hybrid, selected by the Coffee Rust Research Center (CIFC), in Oeiras, Portugal (Várzea et al. 2002). Several authors reported rust resistance in several progenies from crosses in which the Timor Hybrid is a parent (Bonomo et al. 2004, Miranda et al. 2005, Carvalho et al. 2008a, Petek et al. 2008, Capucho et al. 2009).

The yield, which represents the economic value, is one of the most important traits in the selection process, while the populations consist of a mixture of genotypes with different degrees of expression of a number of traits of interest. In coffee, genotype selection based on the mean yield has proved efficient from the third or fourth harvest

\footnotetext{
${ }^{1}$ Embrapa Café, 70.770-901, Brasília, DF, Brazil. ${ }^{2}$ Current address: Empresa de Pesquisa Agropecuária de Minas Gerais (Epamig), Unidade Regional Epamig Zona da Mata. Vila Gianetti, 46/47, Campus da UFV, C.P. 216, 36.570-000, Viçosa, MG, Brazil. *E-mail: antonio.baiao@embrapa.br

${ }^{3}$ Epamig, Unidade Regional Epamig Sul de Minas. Rodovia Lavras/Ijaci, km 02, Campus da UFLA, C.P. 176, 37.200-000, Lavras, MG, Brazil
} 
onwards. According to Mendes and Guimarães (1998), selection efficiency is reasonably high from the fourth harvest onwards. Carvalho et al. (1979) also found that four harvests would be sufficient to compile reliable data on the performance of coffee progenies.

In the genetic breeding of coffee and other plant species, the prediction of gains by a given selection strategy provides a more efficient orientation of breeding programs and the choice of alternative and possibly more effective techniques, based on scientific evidence. However, the selection of superior progenies is time-consuming, since the genetic basis of the most important traits, mostly quantitative, is complex and strongly influenced by the environment (Cruz et al. 2004). Progeny trials with families at different inbreeding levels are a routine procedure in plant breeding programs. By biometric procedures, the genetic variability of these populations can be exploited more efficiently and the genetic gains from selection increased.

The purpose of this study was to evaluate the predicted genetic gains for bean yield, from direct and indirect selection of Arabica coffee progenies originated from genetic combinations, with a view to develop rust-resistant, high-yielding cultivars.

\section{MATERIAL AND METHODS}

The experiment consisted of 98 Arabica coffee genotypes of the Empresa de Pesquisa Agropecuária de Minas Gerais (EPAMIG) grown on the experimental farm Três Pontas (EFTP), in the municipality of Três Pontas, in southern Minas Gerais. Federer's augmented blocks (1955) were used as statistical design, consisting of three blocks with 96 regular treatments $\left(\mathrm{F}_{2}\right)$ and two controls. Six trees per plot were planted on 25/02/2003, spaced 3.50 x $0.90 \mathrm{~m}$. The common regional cultural practices for coffee were applied. The experimental area was classified as clay texture Oxisol. The EFTP is located on a steep slope (lat $21^{\circ} 22^{\prime}$ '01" $\mathrm{S}$, long 45 $30^{\circ} 45^{\prime \prime} \mathrm{W}$ and alt $900 \mathrm{~m}$ asl). The mean annual rainfall and temperature were $1670 \mathrm{~mm}$ and $20.1^{\circ} \mathrm{C}$, respectively.

Of the tested genotypes, 96 represented the $\mathrm{F}_{2}$ generation from hybrid combinations with a view to breed genotypes carrying rust resistance genes and suited for the production of coffee with superior and differentiated beverage quality. The other two genotypes, Catuaí Amarelo IAC 62 and Catuaí Vermelho IAC 15, were used as controls (Tables 1 and 2).
The bean yield (in 60-kg bags of processed coffee per hectare, bg ha-1) of the harvests 2005, 2006, 2007 and 2008 of the 98 genotypes was estimated. Coffee was harvested in June and July and evaluated in liters of coffee fruits per plot. Later the values were converted to $\mathrm{bg} \mathrm{ha}^{-1}$, considering a mean yield of 480 liters of coffee fruits per $60 \mathrm{~kg}$-bag of coffee.

The rust reaction of all plants in the test was assessed in June 2008, before harvest. The following rating scale was adopted (Petek et al. 2008): 1 = no pustules, hypersensitivity reactions, 2 = few leaves with pustules without spores, hypersensitivity reactions, $3=$ few pustules per leaf with high spore production and poorly distributed, $4=$ median number of pustules per leaf with high spore production on the entire plant, $5=$ high number of pustules, high spore production and high leaf drop. No phytosanitary treatment was applied in the experiment.

The following statistical model was applied to analyze the augmented block $Y_{i j}=\mu+\tau_{i}+B_{j}+\varepsilon_{i j}$, where $\mathrm{Y}_{\mathrm{ij}}$ is the trait value for the $\mathrm{i}^{\text {th }}$ treatment in the $\mathrm{j}^{\text {th }}$ block; $\mu$ is the general mean; $\tau_{\mathrm{i}}$ is the effect of the $\mathrm{i}^{\text {th }}$ treatment, which can be decomposed into $\mathrm{T}_{\mathrm{i}}$ (effect of the $\mathrm{i}^{\text {th }}$ control, with $\mathrm{i}$ $=1,2, \ldots, \mathrm{t})$ and $G_{i}^{j}\left(\right.$ effect of the $\mathrm{i}^{\text {th }}$ genotype, with $\mathrm{i}=1,2$, $\left.\ldots, g_{j}\right) ; B_{j}$ is the effect of the $j^{\text {th }}$ block, $j=1,2, \ldots, b$; and $e_{i j}$ is the random error.

The yield data of the four harvests separately, the mean yield of the low-yield (2005 and 2007) and of the high-yield years (2006 and 2008), and the mean of four harvests were statistically analyzed to estimate genetic and non-genetic parameters, some of which were used in expressions to estimate the genetic gain (Mistro et al. 2004). These procedures were performed using software Genes (Cruz 2006a, b).

The 20 best progenies were selected as basis for future selection cycles. The expected genetic gain for direct selection was estimated by the expression: $\mathrm{SG}=h^{2} \mathrm{x}$ DS, where $h^{2}$ is the coefficient of heritability, estimated by the ratio of genotypic by phenotypic variances, which was obtained in the analysis of variance of augmented block; DS is $h^{2}$ the selection differential, given by, $D S=\bar{X}_{s}-\bar{X}_{o}$ where $\bar{X}_{s}$ is the mean of the selected progenies and $\bar{X}_{o}$ is the original progeny mean. The genetic gain by indirect selection were estimated by the expression: $\mathrm{SG}_{\mathrm{y}(\mathrm{x})}=\mathrm{i} \cdot \mathrm{h}_{\mathrm{x}} \cdot \mathrm{r}_{\mathrm{g}} \cdot \mathrm{s}_{\mathrm{gy}}$, where $\mathrm{SG}_{\mathrm{y}(\mathrm{x})}$ is the gain by indirect selection for $\mathrm{Y}$, when selection is practiced on $X, i$ is the selection intensity; $h_{x}$ represents the square root of heritability based on the progeny means; $r_{g}$ is the genotypic correlation between the traits (harvests) $\mathrm{X}$ and $\mathrm{Y}$, and $\mathrm{s}_{\mathrm{gy}}$ is the standard genotypic deviation for trait Y (Cruz et al. 2004). 
ACB Oliveira et al.

Table 1. Genealogy of Arabica coffee progenies

\begin{tabular}{|c|c|c|c|c|}
\hline Progeny & Cross & Generation & Genealogy & $\begin{array}{l}\text { Nr. of } \\
\text { prog. }\end{array}$ \\
\hline Н 842 & $\mathrm{BC}_{1}$ & $\mathrm{~F}_{2}$ & $\begin{array}{l}\text { [H 659-3 (UFV 2190-48 EL } 8=\text { Mundo Novo IAC 464-18x UFV 1603-185] x UFV } \\
\text { 1603-185 [Catimor in the } \text { F }_{4} \text { generation (Caturra Vermelho CIFC } 19 / 1 \text { x Timor hybrid } \\
\text { CIFC 832/1)] }\end{array}$ & 18 \\
\hline H 844 & $\begin{array}{l}\text { three-way } \\
\text { cross }\end{array}$ & $\mathrm{F}_{2}$ & $\begin{array}{l}\text { [H 469-5 (UFV 2190-304 EL } 8=\text { Mundo Novo IAC 464-18 x Timor hybrid UFV 446- } \\
\text { 8)] x Icatu Amarelo Precoce IAC } 3282 \text { - FESP 3282-564 }\end{array}$ & 12 \\
\hline H 845 & $\begin{array}{l}\text { three-way } \\
\text { cross }\end{array}$ & $\mathrm{F}_{2}$ & $\begin{array}{l}\text { [H 469-3 (UFV 2190-304 = Mundo Novo IAC 464-18 EL } 8 \text { x Timor hybrid UFV 446- } \\
\text { 8)] x Icatu Amarelo Precoce IAC 3282 = FESP 3282-564 }\end{array}$ & 3 \\
\hline H 846 & $\begin{array}{l}\text { three-way } \\
\text { cross }\end{array}$ & $\mathrm{F}_{2}$ & $\begin{array}{l}\text { [H 484-3 (UFV 2164-193 EL } 8=\text { Mundo Novo IAC 515-3 x Timor hybrid UFV } 443- \\
\text { 3)] x Icatu Amarelo Precoce IAC } 3282=\text { FESP 3282-202 }\end{array}$ & 3 \\
\hline Н 849 & $\begin{array}{l}\text { three-way } \\
\text { cross }\end{array}$ & $\mathrm{F}_{2}$ & $\begin{array}{c}\text { [H 419-5 (UFV 2143-235 EL } 7 \text { = Catuaí Amarelo IAC } 30 \text { x Timor hybrid UFV 445- } \\
\text { 46)] x Icatu Amarelo Precoce IAC 3282 = FESP 3282-564 }\end{array}$ & 6 \\
\hline H 850 & $\begin{array}{l}\text { three-way } \\
\text { cross }\end{array}$ & $\mathrm{F}_{2}$ & $\begin{array}{c}\text { [H 419-5 (UFV 2143-235 EL } 7 \text { x UFV 445-46) ] x Icatu Amarelo Precoce IAC } 3282= \\
\text { FESP 3282-202 }\end{array}$ & 9 \\
\hline H 851 & $\mathrm{~F}_{1}$ & $\mathrm{~F}_{2}$ & UFV 534-3 c-7 (Caturra Vermelho CIFC 19/1) x Timor hybrid CIFC 4106-76 & 6 \\
\hline H 855 & $\mathrm{BC}_{1}$ & $\mathrm{~F}_{2}$ & $\begin{array}{c}\text { [H 337-2 (UFV 2144-32 EP } 20.1 \text { x Timor hybrid CIFC 832/1)] x UFV 2144-32 EP } \\
20.1 \text { (Catuaí Vermelho IAC 44) }\end{array}$ & 39 \\
\hline
\end{tabular}

\section{RESULTS AND DISCUSSION}

The plant rust response, evaluated prior to the harvest 2008 showed wide variability in the evaluated group of genotypes (Table 2). For this trait, from immune (grade 1) to strongly rust- affected progenies (grades 4 and 5) were observed. This finding may be explained by the genealogy of the progenies, consisting of germplasm Timor Hybrid (rust-resistant) and commercial cultivars such as Mundo Novo and Catuaí (rust-susceptible). This fact made the selection of rust-resistant progenies with high yield capacity possible.

Significant differences were observed $(\mathrm{P}<0.05)$ between treatments for bean yield in the harvests of 2006 (Y06), 2007 (Y07) and 2008 (Y08), measured in $60 \mathrm{~kg}$ bags of processed coffee per hectare $\left(\mathrm{bg} \mathrm{ha}^{-1}\right)$ in the mean lowyield years 2005 and 2007 (Y57), and high-yield years 2006 and 2008 (Y08) and in the mean of the four harvests, from 2005 to 2008 (MYd ). Only in the first harvest, in 2005(Y05), no differences were detected among the progenies for bean yield (Table 3). Therefore, it is safe to say that the mean of one or several treatments can differ from the mean of others in this study.

The results confirmed the occurrence of genetic variability for yield in the set of progenies, indicating the possibility of gains from selection. Other authors also found significant differences among coffee progenies from crosses of commercial cultivars with Timor Hybrid accessions, in bean yield assessments in experiments carried out in Lavras and Campos Altos (Carvalho et al. 2008a) and Patrocínio (Bonomo et al. 2004), in Minas Gerais.
The coefficients of variation estimated for the experimental data of bean yield for the mean of all harvests and the separate harvests were relatively low, except for the harvest of 2005 (Table 3). In terms of the trait coffee bean yield, these values are acceptable, since the genetic control of this trait is complex and highly influenced by environmental conditions. Experimental coefficients of variation with similar magnitudes as in this study were reported by Carvalho et al. (1989) in the evolution of various $\mathrm{F}_{2}$ to $\mathrm{F}_{4}$ coffee progenies from the cross of commercial cultivars with Timor Hybrid accessions and other resistance sources to Hemileia vastatrix.

The high coefficient of experimental variation for the first harvest (Y05) can be attributed to differences in vigor and early growth of seedlings in the nursery and field. These differences in seedling vigor and early growth lead to very disparate yields in the first harvest. However, this difference tends to even out from the second harvest onwards when the plant development is more intense, both of the shoot and root system.

The coefficients of heritability estimated based on progeny means were all $>50 \%$. This fact, coupled with the high variation index (ratio $\mathrm{CVg} / \mathrm{CVe}$ ), all above unity, indicate the predominance of genetic to the detriment of environmental components, reflecting a very advantageous situation for selection for bean yield in the assessed harvests (Table 3). This was also confirmed since the estimates of coefficient of genetic correlations were mostly higher than those estimated for the phenotypic correlations (Table 4). 
Prediction of genetic gains from selection in Arabica coffee progenies

Table 2. Number, description and evaluation of rust reaction of Arabica coffee progenies

\begin{tabular}{|c|c|c|c|c|c|c|c|c|}
\hline $\begin{array}{l}\text { Number } \\
\text { of prog. }\end{array}$ & $\begin{array}{c}\text { Progeny } \\
\text { description }\end{array}$ & $\begin{array}{c}\text { Rust } \\
\text { reaction }^{1}\end{array}$ & $\begin{array}{l}\text { Nr. of } \\
\text { prog. }\end{array}$ & $\begin{array}{c}\text { Progeny } \\
\text { description }\end{array}$ & $\begin{array}{c}\text { Rust } \\
\text { reaction }\end{array}$ & $\begin{array}{l}\text { Nr. of } \\
\text { prog. }\end{array}$ & $\begin{array}{c}\text { Progeny } \\
\text { description }\end{array}$ & $\begin{array}{c}\text { Rust } \\
\text { reaction }\end{array}$ \\
\hline 1 & H 844-5-1 & 3 & 34 & H $842-6-2$ & 1 & 67 & H 849-2-3 & 5 \\
\hline 2 & H 842-6-1 & 3 & 35 & H 849-2-2 & 2 & 68 & H $844-8-3$ & 1 \\
\hline 3 & H 849-2-1 & 5 & 36 & H 844-8-2 & 1 & 69 & H $855-7-3$ & 1 \\
\hline 4 & H 844-8-1 & 4 & 37 & H $855-7-2$ & 1 & 70 & H $855-17-3$ & 2 \\
\hline 5 & Н 855-7-1 & 4 & 38 & H $855-17-2$ & 1 & 71 & H 846-2-3 & 1 \\
\hline 6 & Н $855-17-1$ & 1 & 39 & H $846-2-2$ & 1 & 72 & H $851-8-3$ & 5 \\
\hline 7 & H 846-2-1 & 1 & 40 & H $851-8-2$ & 5 & 73 & H $850-8-3$ & 1 \\
\hline 8 & H 851-8-1 & 5 & 41 & H $850-8-2$ & 1 & 74 & H $850-2-3$ & 3 \\
\hline 9 & H 850-8-1 & 1 & 42 & H $850-2-2$ & 1 & 75 & H $851-10-3$ & 3 \\
\hline 10 & H 850-2-1 & 1 & 43 & H 851-10-2 & 4 & 76 & H 855-9-3 & 3 \\
\hline 11 & H 851-10-1 & 5 & 44 & H 855-9-2 & 3 & 77 & $\mathrm{H}-844-1-3$ & 1 \\
\hline 12 & Н 855-9-1 & 4 & 45 & H-844-1-2 & 3 & 78 & H $855-4-3$ & 1 \\
\hline 13 & H-844-1-1 & 3 & 46 & H $855-4-2$ & 1 & 79 & H $855-2-3$ & 1 \\
\hline 14 & H 855-4-1 & 2 & 47 & H $855-2-2$ & 1 & 80 & H 855-13-3 & 3 \\
\hline 15 & H 855-2-1 & 1 & 48 & H $855-13-2$ & 3 & 81 & H $855-8-3$ & 3 \\
\hline 16 & H 855-13-1 & 2 & 49 & H $855-8-2$ & 1 & 82 & H 842-4-3 & 1 \\
\hline 17 & H $855-8-1$ & 3 & 50 & H $842-4-2$ & 1 & 83 & H 855-19-3 & 2 \\
\hline 18 & H 842-4-1 & 1 & 51 & H $855-19-2$ & 3 & 84 & H 842-1-3 & 1 \\
\hline 19 & Н 855-19-1 & 1 & 52 & H 842-1-2 & 1 & 85 & H $850-5-3$ & 2 \\
\hline 20 & H 842-1-1 & 1 & 53 & H $850-5-2$ & 1 & 86 & H $855-1-3$ & 1 \\
\hline 21 & Н 850-5-1 & 1 & 54 & H $855-1-2$ & 1 & 87 & H $855-15-3$ & 1 \\
\hline 22 & H $855-1-1$ & 1 & 55 & H $855-15-2$ & 1 & 88 & H 849-4-3 & 4 \\
\hline 23 & Н $855-15-1$ & 1 & 56 & H $849-4-2$ & 1 & 89 & H $842-5-3$ & 1 \\
\hline 24 & H 849-4-1 & 4 & 57 & H $842-5-2$ & 1 & 90 & H $855-10-3$ & 1 \\
\hline 25 & H $842-5-1$ & 1 & 58 & H $855-10-2$ & 1 & 91 & H $842-3-3$ & 1 \\
\hline 26 & Н 855-10-1 & 3 & 59 & H 842-3-2 & 1 & 92 & H $855-11-3$ & 5 \\
\hline 27 & H $842-3-1$ & 1 & 60 & H 855-11-2 & 5 & 93 & H 844-9-3 & 1 \\
\hline 28 & Н 855-11-1 & 5 & 61 & H 844-9-2 & 1 & 94 & H-842-7-3 & 4 \\
\hline 29 & H 844-9-1 & 3 & 62 & H-842-7-2 & 2 & 95 & H $855-16-3$ & 2 \\
\hline 30 & H-842-7-1 & 1 & 63 & H 855-16-2 & 4 & 96 & H $845-1-3$ & 1 \\
\hline 31 & Н 855-16-1 & 3 & 64 & H $845-1-2$ & 1 & 97 & Catuaí 62 & 5 \\
\hline 32 & Н 845-1-1 & 1 & 65 & H 844-5-3 & 3 & 98 & Catuaí 15 & 5 \\
\hline 33 & H $844-5-2$ & 4 & 66 & H 842-6-3 & 1 & & & \\
\hline
\end{tabular}

${ }^{1}$ Rust reaction: progenies with grades 1 and 2 are considered resistant and progenies with grades 3 to 5 rust-susceptible.

${ }^{2}$ Catuaí 62 = cultivar Catuaí Amarelo IAC 62 and Catuaí 15 = cultivar Catuaí Vermelho IAC 15.

As commented by Bonomo et al. (2004) and Mistro et al. (2007), the prediction of genetic parameters of a population is of paramount importance in breeding programs. However, for certain traits, the estimation of a parameter may be variable due to the genetic variability in a population and to environmental conditions. With regard to the initial coffee bean productivity, the different estimates for the four harvests and mean yields are probably a result of differential gene expression during plant growth and development, differences in size, vigor and initial seedling development shortly after planting in the field and of environmental conditions in the harvest year. Moreover, the estimates of heritability coefficients must be interpreted with caution. One must be aware of the bias of these estimates since the broad-sense heritability is the ratio of the genetic variance between progenies by the phenotypic variance in experiments conducted at one location only. Consequently, the estimable genetic variance may be inflated by the variance component caused by the genotype $\times$ location interaction.

The direct selection of the 20 best progenies based on bean yield in each year, consecutive harvests from 2005 to 2008 , and based on the mean of the low-yield years (2005 and 2007) and high-yield years (2006 and 2008), aside from the mean yield of all four harvests, resulted in positive gains for this trait in all selection periods (Table 5). The total gains in each harvest or harvest mean ranged from $29.0 \%$ for selection in the growing season of 2006 (Y06) to $238.0 \%$, for selection based on the mean of two low-yield 
ACB Oliveira et al.

Table 3. Summary of individual analysis of variance, considering an average of plots and estimates of some genetic and non-genetic parameters for the trait bean yield $\left(\mathrm{bg} \mathrm{ha}^{-1}\right)$ was evaluated in 98 Arabica coffee genotypes, in the harvests from 2005 a 2008

\begin{tabular}{|c|c|c|c|c|c|c|c|c|}
\hline \multirow{2}{*}{ Sources of variation } & \multirow{2}{*}{ df } & \multicolumn{7}{|c|}{ Mean square $^{1}$} \\
\hline & & Y05 & Y06 & Y07 & Y08 & Y57 & Y68 & MYd \\
\hline Blocks & 2 & 13.02 & 587.90 & 97.83 & 21.46 & 19.84 & 144.65 & 18.32 \\
\hline Treatm. (Adjusted) & 97 & 2.8 & $239.24 *$ & $25.60 *$ & $362.38^{*}$ & $6.47^{*}$ & $193.85 *$ & $47.06^{*}$ \\
\hline \multicolumn{9}{|c|}{ Estimates of genetic and non-genetic parameters ${ }^{2}$} \\
\hline Overall mean & & 1.49 & 51.72 & 5.47 & 53.03 & 3.47 & 52.37 & 27.93 \\
\hline Control mean 1 & & 1.36 & 50.31 & 1.73 & 60.82 & 1.58 & 55.56 & 28.55 \\
\hline Control mean 2 & & 2.44 & 56.19 & 2.20 & 60.91 & 2.32 & 58.55 & 30.44 \\
\hline Control means & & 1.90 & 53.25 & 1.97 & 60.86 & 1.93 & 57.06 & 29.49 \\
\hline Mean progenies & & 1.46 & 51.62 & 5.69 & 52.54 & 3.57 & 52.08 & 27.83 \\
\hline General CV (\%) & & 96.97 & 20.48 & 18.03 & 23.81 & 17.97 & 15.60 & 15.74 \\
\hline $\mathrm{CV}(\%)$ of controls & & 75.98 & 19.90 & 50.21 & 20.74 & 32.25 & 14.32 & 14.91 \\
\hline $\mathrm{CV}(\%)$ of progenies & & 98.67 & 20.52 & 17.34 & 24.03 & 17.49 & 15.69 & 15.80 \\
\hline$h_{m}^{2}(\%)$ & & 51.59 & 56.22 & 96.16 & 57.54 & 94.16 & 66.35 & 60.31 \\
\hline $\mathrm{CVg} / \mathrm{CV} e$ & & 1.03 & 1.13 & 5.00 & 1.16 & 4.01 & 1.40 & 1.23 \\
\hline
\end{tabular}

${ }^{1}$ Y05, Y06, Y07 and Y08: yield, in 60-kg bags of processed coffee per hectare (bg ha ${ }^{-1}$ ), assessed nb the harvests 2005 to 2008; Y57: yield means (bg ha ${ }^{-1}$ ) of the harvests in 2005 and 2007 (low-yield harvests); Y68: yield means (bg ha ${ }^{-1}$ ) of the harvests in 2006 and 2008 (high-yield harvests); and MYd: mean yield (bg ha $\left.{ }^{-1}\right)$ of the four assessed harvests.

${ }^{2}$ Controls 1: Catuaí Amarelo IAC 62; Controls 2: Catuaí Vermelho IAC 15; CV (\%):experimental coefficient of variation; CVg: genotypic coefficient of variation; $h_{m}^{2}$ : coefficients of heritability in the broad-sense, based on the progeny mean; * Significant at $5 \%$ probability, by the $\mathrm{F}$ test.

Table 4. Estimates of genotypic (above the diagonal) and phenotypic correlation coefficients (below the diagonal) for the coffee yield $\left(\mathrm{bg} \mathrm{ha} \mathrm{h}^{-1}\right)$ of the four harvest means separately and averaged together

\begin{tabular}{lccccccc}
\hline & Y05 $^{\mathbf{1}}$ & Y06 & Y07 & Y08 & Y57 & Y68 & -0.34 \\
\hline Y05 & - & 0.35 & -0.09 & -0.81 & 0.18 & -0.31 \\
Y06 & 0.19 & - & -0.43 & 0.47 & -0.31 & 0.83 \\
Y07 & -0.14 & -0.21 & - & -0.96 & -0.26 & -0.28 & -0.89 \\
Y08 & 0.01 & 0.26 & -0.12 & -0.10 & -0.13 & -0.35 \\
Y57 & 0.25 & -0.12 & 0.92 & 0.84 & 0.05 & -0.13 \\
Y68 & 0.12 & 0.75 & -0.19 & 0.82 & 0.98 \\
MYd & 0.17 & 0.73 & -0.02 & - & 0.98 \\
\hline
\end{tabular}

${ }^{1}$ Y05, Y06, Y07 and Y08: yield, in 60-kg bags of processed coffee per hectare (bg ha ${ }^{-1}$ ), assessed in the harvests 2005 to 2008; Y57: yield means (bg ha ${ }^{-1}$ ) of the harvests in 2005 and 2007 (low-yield harvests); Y68: yield means (bg ha ${ }^{-1}$ ) of the harvests in 2006 and 2008 (high-yield harvests); and MYd: mean yield (bg ha ${ }^{-1}$ ) of the four harvests.

years (Y57). Although the total gains were highest for selection in Y05, Y07 and Y57, the low-yield years, it should be noted that the gains in the mean of four harvests (MYd) were low or even negative by this selection strategy. The reason is that the mean bean yield of the selected plants in low-yield years was over $100 \%$ more than the original population mean in these harvests. In Y05, the mean of the selected progenies exceeded the mean of the original population by $213 \%$. Because of the low yield in these harvests, some progenies produced little or no fruit at all and consequently the selection differential (SD), i.e., the difference between the mean of the selected and the original progeny, was lower than estimated for the high-yield years (Table 5).
In general, although the total gains estimated for the high-yield years were lower than those for low-yield years, the indirect gains in the mean of the four harvests (MYd) were higher when selection was performed in growing season of high-yield years (Table 5). This was probably due to the higher contribution of these harvests to the mean of all four.

The direct selection based on mean yield of the highyield years (Y06, Y08 and Y68) provided very similar indirect gains in the mean of four harvests (MYd) to those obtained by direct selection for the trait (Table 5). Twenty progenies selected by direct selection for MYd, 13 (65\%), 13, 16 (80\%) were also selected when selection was performed in Y06, Y08 and Y68, respectively (Table 6). Therefore, under the experimental conditions of this study, the selection for 
Table 5. Estimates of the original mean $(\bar{X})$, averages of the selected progenies $(\bar{X})$, selection differential $(D S)$, heritability of progeny means $\left(h_{m}^{2}\right)$ and selection gains (\% SG) obtained with direct and indirect selection of the 20 best progenies of Arabica coffee, based on yield (bg ha $a^{-1}$ ) between 2005 and 2008

\begin{tabular}{|c|c|c|c|c|c|c|c|c|c|c|c|c|}
\hline \multirow{2}{*}{ Harvest $^{1}$} & \multirow{2}{*}{$X_{o}$} & \multirow{2}{*}{$X_{s}$} & \multirow{2}{*}{$D S$} & \multirow{2}{*}{$h_{m}^{2}$} & \multicolumn{8}{|c|}{ SG $(\%)$ in progenies ${ }^{2}$} \\
\hline & & & & & Y05 & Y06 & Y07 & Y08 & Y57 & Y68 & MYd & Total \\
\hline Y05 & 1.5 & 4.7 & 3.2 & 51.6 & 113.0 & 7.0 & -19.5 & 6.0 & 26.6 & 7.6 & 7.6 & 148.3 \\
\hline Y06 & 51.7 & 71.8 & 20.2 & 56.2 & 6.6 & 21.9 & -22.7 & 12.1 & -14.9 & 19.8 & 16.2 & 29.0 \\
\hline Y07 & 5.6 & 13.6 & 7.9 & 96.2 & -21.6 & -8.2 & 135.9 & -8.5 & 97.9 & -9.7 & -4.3 & 181.5 \\
\hline Y08 & 52.7 & 79.1 & 26.6 & 57.5 & 7.1 & 7.2 & -14.2 & 28.8 & -8.1 & 21.0 & 17.5 & 59.2 \\
\hline Y57 & 3.5 & 7.4 & 3.8 & 94.2 & 15.6 & -3.2 & 124.7 & -1.5 & 103.3 & -2.7 & 1.9 & 238.0 \\
\hline Y68 & 52.2 & 71.6 & 19.5 & 66.3 & 3.5 & 16.4 & -17.5 & 25.9 & -12.0 & 24.7 & 20.5 & 61.3 \\
\hline MYd & 27.9 & 37.5 & 9.7 & 60.3 & 18.7 & 17.1 & -8.2 & 24.7 & 1.1 & 24.4 & 20.8 & 98.5 \\
\hline
\end{tabular}

${ }^{1}$ Y05, Y06, Y07 and Y08: yield, in 60-kg bags of processed coffee per hectare (bg ha ${ }^{-1}$ ), assessed in the harvests 2005 to 2008 ; Y57: yield means (bg ha $\mathrm{h}^{-1}$ ) of the harvests in 2005 and 2007 (low-yield harvests); Y68: yield means (bg ha ${ }^{-1}$ ) of the harvests in 2006 and 2008 (high-yield harvests); and MYd: mean yield (bg ha $\left.{ }^{-1}\right)$ of the four harvests.

${ }^{2}$ Direct SG (\%) = in the main diagonal, in bold; Indirect SG (\%) not in the main diagonal.

Table 6. Respective mean yields $\left(\mathrm{bg} \mathrm{ha}^{-1}\right)$ in direct selection of the 20 best progenies of Arabica coffee in the growing seasons 2005 to 2008

\begin{tabular}{|c|c|c|c|c|c|c|c|c|c|c|c|c|c|}
\hline \multicolumn{2}{|c|}{ Selection in Y05 } & \multicolumn{2}{|c|}{ Selection in Y06 } & \multicolumn{2}{|c|}{ Selection in Y07 } & \multicolumn{2}{|c|}{ Selection in Y08 } & \multicolumn{2}{|c|}{ Selection in Y57 } & \multicolumn{2}{|c|}{ Selection in Y68 } & \multicolumn{2}{|c|}{ Selection in MYd } \\
\hline Prog. & Mean & Prog. & Mean & Prog. & Mean & Prog. & Mean & Prog. & $\overline{\text { Mean }}$ & Prog. & Mean & Prog. & Mean \\
\hline 1 & 5.2 & 1 & 67.9 & 7 & 10.2 & 1 & 69.7 & 3 & 5.5 & 1 & 68.8 & 1 & 36.9 \\
\hline 3 & 6.3 & 3 & 67.9 & 10 & 13.5 & 4 & 97.2 & 4 & 5.5 & 3 & 66.0 & 3 & 35.8 \\
\hline 4 & 4.1 & 5 & 67.9 & 12 & 13.5 & 6 & 69.7 & 7 & 6.0 & 4 & 79.3 & 4 & 42.4 \\
\hline 5 & 5.2 & 13 & 81.1 & 16 & 14.6 & 9 & 69.7 & 9 & 5.5 & 7 & 66.0 & 7 & 36.0 \\
\hline 6 & 4.1 & 14 & 81.1 & 22 & 10.2 & 13 & 72.1 & 10 & 7.7 & 13 & 76.6 & 13 & 40.2 \\
\hline 9 & 4.1 & 30 & 81.1 & 32 & 10.2 & 33 & 100.4 & 12 & 7.1 & 33 & 70.8 & 21 & 35.8 \\
\hline 14 & 6.0 & 37 & 75.3 & 36 & 10.2 & 41 & 80.6 & 16 & 8.8 & 37 & 69.1 & 30 & 35.3 \\
\hline 15 & 5.2 & 43 & 75.3 & 39 & 19.9 & 42 & 69.5 & 30 & 7.8 & 41 & 71.3 & 33 & 37.0 \\
\hline 16 & 3.0 & 59 & 73.1 & 44 & 12.0 & 43 & 82.8 & 32 & 6.0 & 43 & 79.0 & 37 & 35.6 \\
\hline 19 & 4.7 & 62 & 75.3 & 48 & 12.4 & 47 & 82.8 & 36 & 6.3 & 47 & 70.4 & 41 & 37.5 \\
\hline 20 & 3.0 & 76 & 68.5 & 50 & 12.4 & 51 & 89.4 & 39 & 10.1 & 51 & 69.8 & 43 & 40.6 \\
\hline 21 & 3.0 & 83 & 68.5 & 53 & 14.6 & 52 & 76.2 & 44 & 6.1 & 52 & 69.1 & 47 & 36.3 \\
\hline 25 & 4.1 & 84 & 68.5 & 67 & 23.5 & 53 & 69.5 & 48 & 7.4 & 59 & 69.1 & 51 & 35.6 \\
\hline 29 & 9.6 & 85 & 68.5 & 68 & 10.2 & 54 & 69.5 & 50 & 6.3 & 62 & 79.0 & 52 & 35.8 \\
\hline 30 & 6.0 & 88 & 73.4 & 71 & 13.8 & 62 & 82.8 & 53 & 9.1 & 84 & 77.6 & 59 & 35.2 \\
\hline 37 & 2.9 & 89 & 68.5 & 75 & 10.2 & 84 & 86.8 & 67 & 11.3 & 88 & 69.1 & 62 & 40.6 \\
\hline 41 & 4.6 & 93 & 68.5 & 76 & 10.5 & 86 & 78.0 & 71 & 6.7 & 89 & 66.6 & 84 & 39.3 \\
\hline 53 & 3.5 & 94 & 68.5 & 77 & 16.9 & 90 & 78.0 & 77 & 9.3 & 93 & 72.1 & 88 & 35.9 \\
\hline 73 & 2.9 & 96 & 68.5 & 80 & 19.5 & 93 & 75.8 & 80 & 9.3 & 94 & 66.6 & 93 & 38.7 \\
\hline 81 & 6.6 & 97 & 67.9 & 82 & 12.9 & 96 & 81.3 & 82 & 6.6 & 96 & 74.9 & 96 & 38.8 \\
\hline Mean & 4.7 & & 71.8 & & 13.6 & & 79.1 & & 7.4 & & 71.6 & & 37.5 \\
\hline
\end{tabular}

${ }^{1}$ Y05, Y06, Y07 and Y08: yield, in 60-kg bags of processed coffee per hectare (bg ha ${ }^{-1}$ ), assessed in the harvests 2005 to 2008 ; Y57: yield means (bg ha ${ }^{-1}$ ) of the harvests in 2005 and 2007 (low-yield harvests); Y68: yield means (bg ha ${ }^{-1}$ ) of the harvests in 2006 and 2008 (high-yield harvests); and MYd: mean yield (bg ha ${ }^{-1}$ ) of the four harvests.

yield could be performed already in the first high-yield year (Y06), without significant losses in relation to the possible genetic gains by selection based on the mean of all four harvests. These losses in yield gain would be even smaller if selection were based on the mean of the two high-yield years (Y68). These results agree with the statements of renowned coffee breeders (Carvalho et al.
1969, Fazuoli et al. 2005), who suggested that the highyield years are best suited for selection for bean yield.

Notably, the above observations may be justified by the estimates of correlations (Table 4) between the mean yield of the four assessed harvests (MYd), and the other harvests (Y05,Y06, Y07, and Y68).For these results, one can observe negative correlations between MYd and low- 


\section{ACB Oliveira et al.}

yield years and positive and high coefficients between MYd and high-yield years. The previous finding is very important in the case of coffee, in view of the high labor demand in the process of harvesting and evaluating large numbers of plants and experimental plots involved in the study of genetic breeding.

The progenies selected in this study, based on yield capacity and with no rust symptoms in the field, will be evaluated by sensory analysis by a trained panel of the Brazil Specialty Coffee Association - BSCA, to test the beverage quality and the possibility of using these progenies as future cultivars for the specialty coffee market.

Therefore, it can be concluded that there is enough genetic variability in the progeny group for the traits bean yield and rust resistance for a selection with possible gains. The direct selection for yield provides positive genetic gains, increasing the frequency of favorable alleles in the population. Under the experimental conditions of this study, selection for yield can be performed in the first high-yield year, without major losses compared to gains that would be obtained by genetic selection based on the mean of four harvests.

\section{ACKNOWLEDGEMENTS}

The authors thank the Consórcio Brasileiro de Pesquisa e Desenvolvimento do Café (CBP\&D/Café) and the Fundação de Amparo à Pesquisa do Estado de Minas Gerais (FAPEMIG) for funding this research.

\section{Predição de ganhos genéticos por seleção em progênies de café arábica}

RESUMO - Os ganhos por seleção para produtividade foram estimados em progênies de café arábica portadoras de fatores de resistência à ferrugem. O experimento foi instalado no município de Três Pontas, $M G$, no delineamento de blocos aumentados. Foram constituídos três blocos com 96 tratamentos regulares (progênies $F_{2}$ ) e dois comuns (testemunhas). O espaçamento foi de 3,50 $x$ $0,90 \mathrm{~m}$, com seis plantas por parcela. A reação das plantas à ferrugem foi avaliada, por notas, em 2008. A produtividade (sc ha-1) foi estimada nas safras de 2005 a 2008. Houve diferenças significativas entre tratamentos para produtividade em todas as colheitas avaliadas, exceto 2005. A presença de variabilidade genética entre as progênies permitiu expressivos ganhos em produtividade pela seleção. Nas condições experimentais desta pesquisa, a seleção para produtividade de grãos pode ser efetuada na primeira safra alta, sem grandes prejuízos em relação aos ganhos genéticos obtidos pela seleção baseada na média de quatro colheitas.

Palavras-chave: Coffea arabica; melhoramento genético; produtividade de grãos; resistência à ferrugem; progresso genético.

\section{REFERENCES}

Bonomo P, Cruz CD, Viana JMS, Pereira AA, Oliveira VR and Carneiro PCS (2004) Avaliação de progênies obtidas de cruzamentos de descendentes do Híbrido de Timor com as cultivares Catuaí Vermelho e Catuaí Amarelo. Bragantia 63: 207-219.

Capucho AS, Caixeta ET, Zambolim EM and Zambolim L (2009) Herança da resistência do Híbrido de Timor UFV 443-03 à ferrugem-do-cafeeiro. Pesquisa Agropecuária Brasileira 44: 276-282.

Carvalho A, Fazuoli LC and Costa WM (1989) Melhoramento do cafeeiro: XLI. Produtividade do Híbrido de Timor, de seus derivados e de outras fontes de resistência a Hemileia vastatrix. Bragantia 48: 73-86.
Carvalho A, Fewerda FP, Frahm-Leliveld JA, Medina DM, Mendes AJT and Mônaco LC (1969) Coffee. In Fewerda FP (ed) Outlines of perennial crop breeding in the tropics. Veenman, Wageningen, p.189-241.

Carvalho A, Mônaco LC and Fazuoli LC (1979) Melhoramento do cafeeiro. XL - Estudos de progênies e híbridos de café Catuaí. Bragantia 38: 202-216.

Carvalho AM, Pereira AA, Carvalho GR, Mendes ANG and Botelho CE (2008a) Avaliação de progênies de cafeeiros obtidas do cruzamento entre Catuaí e Híbrido de Timor. Scientia Agraria 9: 249-253.

Carvalho CHS, Fazuoli LC, Carvalho GR, Guerreiro-Filho O, Pereira AA, Almeida SR, Matiello JB, Bartholo GF, Sera T, Moura WM, Mendes ANG, Rezende JC, Fonseca AFA, Ferrão MAG, Ferrão RG, Nacif AP, Silvarolla MB and Braghini MT (2008b) Cultivares de café arábica de porte baixo. In Carvalho CHS (ed) Cultivares de café: origem, características e recomendações. Embrapa Café, Brasília, p.157-226. 
Cruz CD (2006a) Programa Genes: biometria. UFV, Viçosa, 382p.

Cruz CD (2006b) Programa Genes: estatística experimental e matrizes. UFV, Viçosa, 285p.

Cruz CD, Regazzi AJ and Carneiro PCS (2004) Modelos biométricos aplicados ao melhoramento genético. $3^{\text {rd }}$ ed., vol.1, UFV, Viçosa, 480p.

Fazuoli LC, Carvalho CSH, Carvalho GR, Guerreiro-Filho O, Pereira AA, Bartholo GF, Moura WM, Silvarolla B and Braghini MT (2008) Cultivares de café arábica de porte alto. In Carvalho CHS (ed) Cultivares de café: origem, características e recomendações. Embrapa Café, Brasília, p. 227-254.

Fazuoli LC, Guerreiro-Filho O, Silvarolla MB and Medina Filho HP (2005) Avaliação das cultivares Mundo Novo, Bourbon Amarelo e Bourbon Vermelho de Coffea arabica L., em Campinas, SP. Bragantia 64: 533-545.

Federer WT (1955) Experimental design: theory and application. MacMillan, New York, 544p.

Mendes ANG and Guimarães RJ (1998) Genética e melhoramento do cafeeiro. UFLA, Lavras, 99P.

Miranda JM, Perecin D and Pereira AA (2005) Produtividade e resistência à ferrugem do cafeeiro (Hemileia vastatrix Berk. et Br.) de progênies $\mathrm{F}_{5}$ de Catuaí Amarelo com o Híbrido de Timor. Ciência e Agrotecnologia 29: 1195-1200.
Mistro JC, Fazuoli LC, Gallo PB, Oliveira ACB, Toma-Braghini M and Silvarolla MB (2007) Estimates of genetic parameters in Arabic coffee derived from Timor Hybrid. Crop Breeding and Applied Biotechnology 7: 141-147.

Mistro JC, Fazuoli LC, Gonçalves PS and Guerreiro-Filho O (2004) Estimates of genetic parameters and expected genetic gains with selection in robust coffee. Crop Breeding and Applied Biotechnology 4: 86-91.

Oliveira ACB and Pereira AA (2008) Cultivares de café portadoras de fatores de resistência à ferrugem indicadas para plantio em Minas Gerais. Epamig, Belo Horizonte, 7p. (Circular Técnica, 34)

Petek MR, Sera T and Fonseca (2008) Predição de valores genéticos aditivos na seleção visando obter cultivares de café mais resistentes à ferrugem. Bragantia 67: 133-140.

Várzea VMP, Rodrigues Junior CJ, Silva MC, Gouveia M, Marques DV, Guerra-Guimarães L and Ribeiro A (2002) Resistência do cafeeiro a Hemileia vastatrix. In Zambolim L (ed.) O estado da arte de tecnologias na produção de café. Editora UFV, Departamento de Fitopatologia, Viçosa, p. 297-320.

Zambolim L, Vale FXR, Costa H, Pereira AA and Chaves GM (2002) Epidemiologia e controle integrado da ferrugem do cafeeiro. In Zambolim L (ed.) $O$ estado da arte de tecnologias na produção de café. Editora UFV, Departamento de Fitopatologia, Viçosa, p. 369-450. 